\title{
Stability of Ni / TiB 2 Coating on Cucrzr Electrodes for Resistance Spot Welding Galvanized Steel Sheet
}

Pavol Sejč, Peter Jaško, Peter Baksa, Judita Belanová

Faculty of Mechanical Engineering, Slovak University of Technology in Bratislava, Pionierska 15, 83102 Bratislava, Email: pavol.sejc@stuba.sk

Under the influence of heat load and $\mathrm{Zn}$ diffusion in resistance spot welding of galvanized steel sheets, significant changes occur on the contact area of $\mathrm{CuCrZr}$ welding electrodes which lead to their erosion damage. Changes, causing wear of electrodes not only affect the welding process but also the quality and properties of the weld. Apart from the traditional solution (for example, the so-called "Slope" welding current) the wear of the contact surfaces can be affected by using the barrier layers - coatings. Main goal for the use of material barrier is to minimize the structural changes caused by $\mathrm{Zn}$ diffusion, erosion and higher heat resistance of the electrode. Recent studies have shown that such a suitable coating is a multilayer system $\left(\mathrm{Ni} / \mathrm{TiB}_{2}\right)$.

This paper is focused on the assessment of changes in the contact area of the electrodes and the barrier layer $\mathrm{Ni} / \mathrm{TiB}_{2}$ after compila-tion $0,1,5,20$ and 100 welds on galvanized steel sheets type HX220BD Z100MBO.

Keywords: Resistance Spot Welding, Electro spark deposition, welding electrode, barrier coating,

\section{Acknowledgment}

The results presented in this paper were achieved as a part of the VEGA grant No. 1/0385/15.

\section{References}

[1] MEŠKO, J., ZRAK, A., MULCZYK, K., TOFIL, S. (2014). Microstructure analysis of welded joints after laser welding. Manufacturing Techology: journal of science, research and production, Vol. 14, No. 3, ISSN 1213-2489.

[2] KVASNiCOVÁ, P., NOVÁK, V., NOVÁK, D., (2016). Computer Simulation of Laser Welding Technology of Chrome-Nickel Steels in Automotive Industry and its Verification by Means of Electron Microscopy. Manufacturing Techology: journal of science, research and production, Vol. 16, No.5, ISSN 1213-2489.

[3] JAŠČÁK, L., BREZINOVÁ J., HALAMA M., VIŇÁŠ J. (2011). Quality Evaluation of Resistance Spot Welds of Hot-Dip Galvanized Sheets In Corrosive Enviroment., Chemické listy, Vol. 105., No. 17, pp.709-712, ISSN 00092770.

[4] BROŽEK, M., (2016). Resistance Spot Welding of Steel Sheets. Manufacturing Techology: journal of science, research and production, Vol. 16, No. 4, ISSN 1213-2489.

[5] DE, A., DORN, L., GUPTA, O. (2000). Analysis and Optimisation of Electrode Life for Conventional and Compound Tip Electrodes During Resistance Spot Welding of Electrogalvanised Steels, Sci. Technol. Weld. Join. Vol. 5.

[6] HOWE, P a KELLY, S C. (1988) A comparison of the resistance spot weldability of bare,hot-dipped, galvannealed, and electrogalvanized DQSK sheet steels., International Congress and Exposition.

[7] GEDEON, S.A. A EAGAR, T.W., (1986). Resistance Spot Welding of Galvanized Steel: Part I. Material Variations and Process Modifications., Metalurgical Transactions B, Vol. 17B.

[8] JAŠKO, P., SEJČ, P. A BAKSA, P. (2015). Štúdium zmien na povrchu zvarových spojov a elektród s povlakom $\mathrm{Ni}$ /TiB2 pre odporové bodové zváranie pozinkovaných ocel'ových plechov., Zváranie, Vol. 63, No. 11-12, ISSN $0044-5525$

[9] VW 01105-1., (2007). Odporové bodové zváranie. Konštrukcia. Výpočet. Nepovrstvené a povrstvené plechy

[10] MCLEOD, A. D., HAGGERTY, D. R. A SADOWAY, D. R. (1984). Electrical resistivites of Monocrystalline and Polycrystalline TiB2., Journal of the American ceramic Society, Vol. 67, No. 11, pp.705-708.

[11] ZHIGANG, HOU, ILL-SOO, K., YUANXUN, W., CUNZHI, L., CHUANYAO CH. (2007). Finite element analysis for mechanical features of resistance spot welding process. Journal of Materials Processing Technology, Vol. 185

[12] MOSHAYEDI, H. A SATTARI-FAR, I. (2013). Resistance spot welding and the effects of welding time and current. Mechanical Engineering Department, Amirkabir University of Technology . 